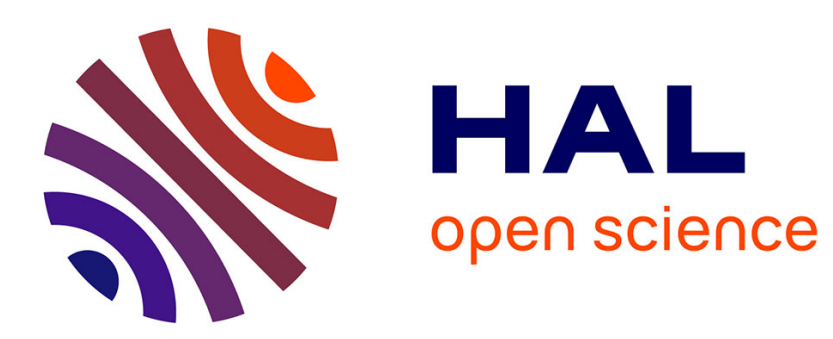

\title{
On the interface positioning in a Zonal Detached Eddy Simulation (ZDES) of a spatially developing flat plate turbulent boundary layer
}

N. Renard, S. Deck

\section{- To cite this version:}

N. Renard, S. Deck. On the interface positioning in a Zonal Detached Eddy Simulation (ZDES) of a spatially developing flat plate turbulent boundary layer. 5th Symposium on Hybrid RANS/LES Methods, Mar 2014, HOUSTON, United States. hal-01079236

\section{HAL Id: hal-01079236 \\ https://hal.science/hal-01079236}

Submitted on 31 Oct 2014

HAL is a multi-disciplinary open access archive for the deposit and dissemination of scientific research documents, whether they are published or not. The documents may come from teaching and research institutions in France or abroad, or from public or private research centers.
L'archive ouverte pluridisciplinaire HAL, est destinée au dépôt et à la diffusion de documents scientifiques de niveau recherche, publiés ou non, émanant des établissements d'enseignement et de recherche français ou étrangers, des laboratoires publics ou privés. 
Session:

\title{
On the interface positioning in a Zonal Detached Eddy Simulation (ZDES) of a spatially developing flat plate turbulent boundary layer
}

\author{
N. Renard, S. Deck \\ ONERA, The French Aerospace Lab, F-92190 Meudon, France
}

Mean quantities in attached turbulent boundary layers are provided by RANS simulations, but resolving the most energetic turbulent fluctuations is sometimes needed (e.g. mild flow separation sensitive to the upstream history of the boundary layer, dynamic loading and noise predictions). A DNS and even a wall-resolved LES at the highest Reynolds numbers relevant to the industry is extremely expensive, mainly because of the very small structures to be resolved in the inner layer (see [1]). This motivates wall-modelled LES (WMLES), where the inner layer is modelled and most of the turbulent kinetic energy in the outer layer is resolved. Among the WMLES techniques, some hybrid RANS/LES methods use a RANS domain as a wall model while the outer layer is resolved in LES. The present study investigates the sensitivity to the RANS/LES interface position in one such method, the mode 3 of the ZDES technique (see [2]).

A flat plate turbulent boundary layer is simulated in the range $3150 \leq$ $\mathrm{Re}_{\theta} \leq 13000$, with three interface positions: $\mathrm{y}_{\text {interface }}=0.1 \delta, \mathrm{y}^{+}{ }_{\text {interface }}=200$ and $\mathrm{y}^{+}$interface $=3.9 \mathrm{Re}_{\tau}^{1 / 2}$. The mesh has a $200^{+}$streamwise- and $100^{+}$ spanwise spacing. Comparisons are made with a ZDES simulation on a much finer mesh $\left(50^{+}\right.$streamwise- and $12^{+}$spanwise spacing $)$.

The instantaneous flow field is visualised in figures 1-2 (fine and coarse meshes). The inner RANS zone contains resolved Reynolds stresses (figures 3-4). The Reynolds shear stress is slightly underestimated, including in the outer layer (fig. 4). Its co-spectrum (figure 6) shows that this is partially caused by a lack of spectral content at long wavelengths with the coarse mesh compared with the fine mesh. Using the FIK identity [3], the contribution of the Reynolds shear stress to turbulent mean skin friction can be assessed as $C_{f, 2}=-4 \int_{0}^{1} \frac{\left\langle u^{\prime} v^{\prime}\right\rangle}{U_{\infty}^{2}}\left(1-\frac{y}{\delta}\right) d\left(\frac{y}{\delta}\right)$. The resolved fraction of $\mathrm{C}_{\mathrm{f}, 2}$ is shown in figure 5. The modelled fraction is negligible with the fine mesh, while it depends on the position of the interface with the coarser mesh. Especially $\mathrm{y}^{+}{ }_{\text {interface }}=3.9 \mathrm{Re}_{\tau}^{1 / 2}$ provides a higher resolved fraction of $\mathrm{C}_{\mathrm{f}, 2}$ than $\mathrm{y}_{\text {interface }}=0.1 \delta$. A thorough investigation will be provided in the final version. 
Session:

\section{References}

[1] U. Piomelli, Wall-layer models for large-eddy simulations, Prog. in Aerosp. Sc. 44 (2008)

[2] S. Deck, "Recent improvements of the Zonal Detached Eddy Simulation (ZDES) formulation", Theoretical and Computational Fluid Dynamics 26 (2012)

[3] K. Fukagata, K. Iwamoto, and N. Kasagi, "Contribution of Reynolds stress distribution to the skin friction in wall-bounded flows", Physics of Fluids, 14 (2002)

[4] D.B. DeGraaff and J.K. Eaton, "Reynolds number scaling of the flat-plate turbulent boundary layer." Journal of Fluid Mechanics, 422 (2000)

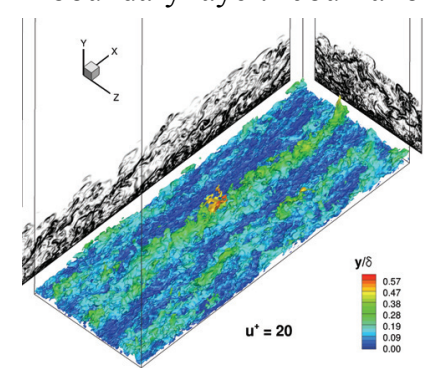

Fig. 1 Isosurface of $u$ and density gradient magnitude, fine mesh $\left(50^{+} / 12^{+}\right)$

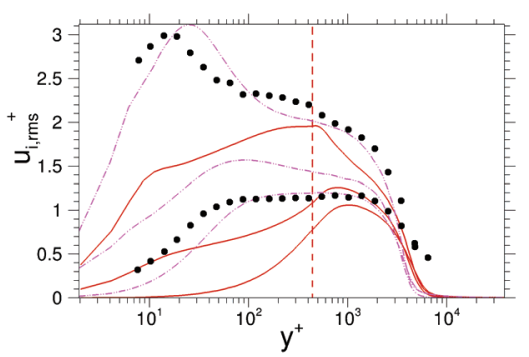

Fig. 3 Normal Reynolds stresses; _ : $\left(200^{+} / 100^{+}\right)$ mesh, $\mathrm{y}_{\text {interface }}^{+}=0.1 \delta ; \ldots . .:\left(50^{+} / 12^{+}\right)$mesh; ...: exp. data from [4] for $\mathrm{u}_{\mathrm{rms}}$ and $\mathrm{v}_{\mathrm{rms}}$

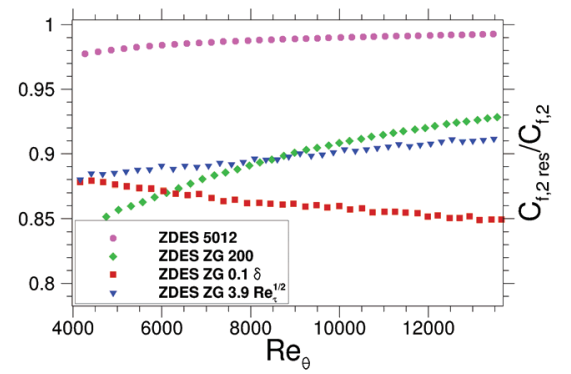

Fig. 5 Resolved fraction of $\mathrm{C}_{\mathrm{f}, 2} \ldots$...: $\left(200^{+} / 100^{+}\right)$ mesh; ....: $\left(50^{+} / 12^{+}\right)$mesh.

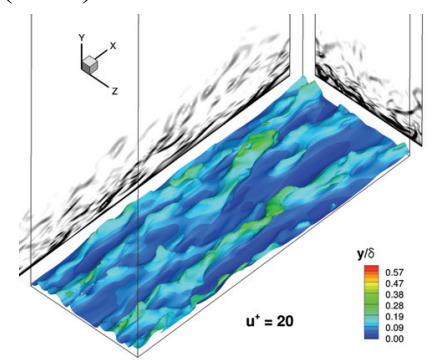

Fig. 2 Same quantities on the coarse $\left(200^{+} / 100^{+}\right)$ mesh, $\mathrm{y}^{+}$interface $=0.1 \delta$.

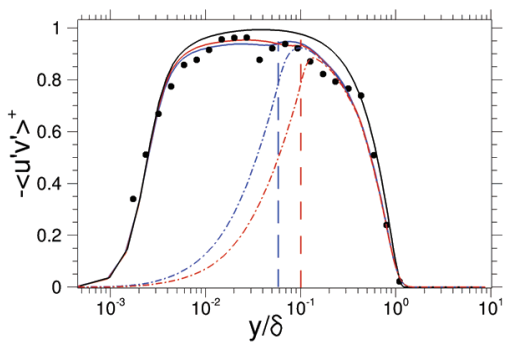

Fig. 4 Reynolds shear stress; $\left(200^{+} / 100^{+}\right)$mesh, _ $\mathrm{y}^{+}{ }_{\text {interface }}=0.1 \delta, \ldots: \mathrm{y}^{+}{ }_{\text {interface }}=3.9 \mathrm{Re}_{\tau}^{1 / 2}, \ldots$ : total stress, _...: resolved stress; _ : RANS, ...: exp. data from [4]

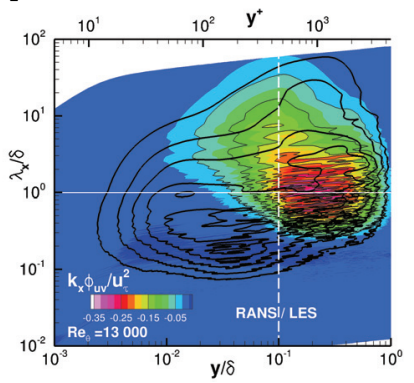

Fig. 6 Co-spectrum of the resolved Reynolds shear stress. Colours: $\left(200^{+} / 100^{+}\right)$mesh, $\mathrm{y}_{\text {interface }}=0.1 \delta$. Lines: $\left(50^{+} / 12^{+}\right)$mesh. 